\title{
Seasonal Differences in Rural Particulate Matter Ecotoxicity
}

\author{
Nora Kováts ${ }^{1}\left[\right.$. Virág Adrienn Fábián ${ }^{1} \cdot$ Katalin Hubai $^{1} \cdot$ Dorina Diósi $^{1} \cdot$ Tsend-Ayush Sainnokhoi $^{1} \cdot$ Zsófia Békéssy $^{1}$. \\ Gábor Teke ${ }^{2}$
}

Received: 25 February 2020 / Revised: 3 May 2020 / Accepted: 21 May 2020 / Published online: 29 May 2020

(c) The Author(s) 2020

\begin{abstract}
The composition of atmospheric particulate matter, including particle-bound polyaromatic hydrocarbons, generally shows a clear seasonal pattern which is reflected in its ecotoxicity as well. This study aimed at characterising seasonal differences in the ecotoxicity of rural aerosol samples applying both luminescent bacteria and higher plants as test organisms. Higher plant phytotoxicity was assessed by the Sinapis alba root growth inhibition test and the Vegetative Vigour Test. Different bioassays and end-points showed different sensitivity: while the Sinapis alba assay showed no toxic effect, luminescent bacteria proved an excellent screening tool, detecting no toxicity in the summer sample and the highest inhibition in the winter sample, with $\mathrm{EC}_{20}=9.87 \%$. In the case of Vegetative Vigour Test, parallel application of different end-points revealed that atmospheric particulate matter might have a Janus-faced effect: stimulation of photosynthetic pigments due to nutrient content and growth impairment due to toxic components.
\end{abstract}

Keywords Atmospheric particulate matter · PM2.5 ecotoxicity · Vibrio fischeri · Terrestrial plant test

\section{Introduction}

Particulate matter (PM) is considered by the national and international regulatory agencies as one of the most harmful air pollutants to human health (WHO 2013). In the European Union, threshold levels are set for $10 \mu \mathrm{m}$-diameter (PM10) and 2.5 $\mu \mathrm{m}$-diameter (PM2.5) particles (European Parliament C. Directive 2008/50/EC of the European Parliament and of the Council of 21 May 2008 on ambient air quality and cleaner air for Europe; 2008). These standard limit values are, however, exceeded not only in many large European cities (Reche et al. 2011) but in rural areas as well (EEA 2017). In addition, while no limit values are available for smaller particles (PM1 and below), the risk associated with them might even be higher, as they bind relatively higher amounts of potentially hazardous toxic compounds (Valavanidis et al. 2006).

Nora Kováts

kovats@almos.uni-pannon.hu

1 Institute of Environmental Sciences, University of Pannonia, Egyetem str. 10, Veszprém 8200, Hungary

2 ELGOSCAR-2000 Environmental Technology and Water Management Ltd, Balatonfuzfo 8184, Hungary
PM consists of an elemental carbon core adsorbing a large number of potentially toxic substances such as polyaromatic hydrocarbons (PAHs) (Health Effects Institute 2002). They are generated during the incomplete combustion of carbon-containing substances, such as wood, or fossil fuels (Shen et al. 2011).

Generally, PAH concentrations show considerable seasonal variation, reaching maxima in cold seasons (Morville et al. 2011). It can be attributed to numerous factors, such as lower atmospheric mixing heights, lower wind speed, lower rate of photochemical oxidation of PAHs by solar radiation, and naturally, higher contribution of combustion-related emissions (Teixeira et al. 2012). Eiguren-Fernandez et al. (2004) compared the seasonal pattern of both vapor- and fine-particle-phase PAHs and observed the highest seasonal difference for particle-phase PAHs.

Relatively few ecotoxicological studies have addressed the risk PM2.5 poses on the non-human biota. In general, for assessing the ecotoxicity of atmospheric PM, the most often applied test is based on the bioluminescence inhibition of the Gram-negative, marine bacterium Vibrio fischeri (Kováts 2020). Toxic compounds will reduce the NAD(P) H:FMN oxidoreductase and luciferase enzyme system activity, which is reflected in the rapid decrease of light emittance of the bacterium. 
The $V$. fischeri assay has proven a good screening tool in the study of Marti et al. (Marti et al. 2015) when cytotoxicity of PM2.5 collected in the nearby area of cement plants was analysed. Luminescent bacteria test results were in harmony with cytotoxicity assessed on human lung epithelial cell lines. Aammi et al. (2017) employed this assay on PM2.5 samples to identify threshold levels for toxicity in Istanbul (Turkey) which were set as $1.11 \mathrm{TU}$ (Toxicity Unit, which is calculated as $1 / \mathrm{EC}_{50} \times 100$ ).

In some cases, the source of potential toxicity was also studied. Wang et al. (2016) used the bioluminescent bacteria to characterise particulate matter ecotoxicity in Nanjing (China). The toxicity of the samples was attributed to both organics and metals. Evagelopoulos et al. (2009) found significant correlation between $V$. fischeri ecotoxicity and PAH content of PM2.5 samples collected in a heavily industrialized area in the north-western part of Greece.

In addition to internationally accepted standards, the bioassay is subject to further improvements. Kessler et al. (2012) developed a reporter panel of 9 genetically engineered bacterial (Escherichia coli) strains which also reflect different stress conditions with the change in the light signal. The panel was evaluated on different anthropogenic PM2.5 samples such as vehicle combustion particles, coal fly ash samples, and an urban dust sample.

In addition to luminous bacteria, other bacterial assays are available, though they have been quite rarely employed. Filep et al. (2015) adapted the ISO 137 10712:1995 Pseudomonas putida growth inhibition test to evaluate the toxicity of winter PM2.5 samples and found that biomass burning was the main factor triggering a cytotoxic response.

Bioassays based on higher organisms are also in use. Verma et al. (2013) estimated the toxicity of urban PM2.5 using the freshwater rotifer Brachionus calyciflorus. Ambient particles, in general, were toxic to the rotifers, $>70 \%$ of toxicity was associated with the hydrophobic fraction of $\mathrm{PM}$. Another widely used test organism, the nematode $\mathrm{Cae}$ norhabditis elegans was applied in the study of Zhao et al. (2014) for investigating the deleterious effects of PM2.5 urban aerosol collected in Beijing. Not only acute exposure elucidated toxic effects but prolonged exposure was reported to cause chronic effects such as a decrease in reproduction success and even in lifespan in the progeny of the exposed organisms.

To evaluate the environmental hazard posed by chemicals or a mixture of chemicals, a carefully composed battery of biotests should be used, possibly representing different functional and/or taxonomic groups (Bierkens et al. 1998). The Vibrio fischeri bioassay has often been coupled with plant tests (e.g. Baran and Tarnawski 2013; Barbosa et al. 2013). In both bacteria and higher plants, reactive oxygen species (ROS) production is the main stressor being responsible for the toxic effect (El-Alawi et al. 2002; Pašková et al. 2006).
In a study of Wang et al. (1998) ecotoxicity of urban dust samples was assessed on a battery of tests including the higher plants Brassica chinensis and Lolium perenne, and the luminescent bacterium Photobacterium phosphoreum. Characterising the chemical composition of the samples, the bacterial test showed significant correlation with heavy metals such as lead and zinc while no specific trend was observed for higher plants.

The objective of the study reported here was to characterise seasonal differences in rural PM, comparing the sensitivity of different test organisms (bacteria and higher plants) and also, of different test end-points.

\section{Materials and Methods}

\subsection{Sample Collection and Preparation}

PM2.5 aerosol samples were collected in K-puszta (Hungary, $46^{\circ} 58^{\prime} \mathrm{N}, 19^{\circ} 33^{\prime} \mathrm{E}$ ) (Fig. 1). This measuring station is part of the Hungarian Meteorological Service, and also of the WMO (World Meteorological Organization), the GAW (Global Atmospheric Watch), the EUSAAR (European Super-sites for Atmospheric Aerosol Research) and the EMEP (European Monitoring and Evaluation Programme). The station's function is the measurement of background pollution (Horváth and Sutton 1998; Maenhaut et al. 2017).

The composite sample was prepared in case of every season, composing of 25 filters. Filters were selected to cover the meteorological season (Spring runs from March 1 to May 31; Summer runs from June 1 to August 31; Autumn runs from September 1 to November 30; and Winter runs from December 1 to February 28). To gain extract of sufficient volume for spraying, the filters were cut in pieces and placed in a beaker filled with $1000 \mathrm{ml}$ high purity (MilliQ) water. Extraction took $24 \mathrm{~h}$, during that time filters were regularly stirred. Finally, the extract was filtered on a $0.45 \mu \mathrm{m}$ pore size filter and stored in a freezer until use.

\subsection{Analytical Measurements}

PAHs were measured by Agilent 6890GC 5973E MSD GC-MS according to MSZ 1484-6:2003. All analyses were provided by the Laboratory of the ELGOSCAR-2000 Environmental Technology and Water Management Ltd, accredited by the (Hungarian) National Accreditation Authority (registration number NAH-1-1278/2015).

\subsection{Ecotoxicity Testing}

\subsubsection{Vibrio fischeri Bioluminescence Inhibition Test}

The test was conducted according to ISO 21338:2010: water quality - kinetic determination of the inhibitory effects of 
sediment, other solids and color samples on the light emission of Vibrio fischeri (kinetic luminescent bacteria test). The kinetic protocol was especially designed to measure the light output of test bacteria in turbid or colored samples (Lappalainen et al. 1999, 2001).

The tests were carried out in the Luminoskan Ascent Luminometer (Thermo Scientific). Prior to measurements, freeze-dried photobacteria were rehydrated with the reconstitution solution and stabilized at $15^{\circ} \mathrm{C}$ for $15 \mathrm{~min}$. Testing was conducted in a 96-well plate, each sample was measured in 2 replicates. After the sample was added to the bacterial suspension, bioluminescence intensity was continuously recorded for the first $30 \mathrm{~s}$. After $30 \mathrm{~min}$ exposure, luminescence intensity was read again. The light output of the unstressed bacteria (the first $30 \mathrm{~s}$ ) was used as a reference in calculating the results.

$\mathrm{EC}_{20}$ values were calculated from the light inhibition percentages by the Aboatox software provided with the Luminoskan Ascent Luminometer.

\subsection{Vegetative Vigour Test}

The No. 227 OECD GUIDELINE FOR THE TESTING OF CHEMICALS: Terrestrial Plant Test: Vegetative Vigour Test assesses the potentially deleterious effect of the sample by spraying it onto the above-ground parts of the test plants. The Guideline recommends crop species proven suitable for phytotoxicity testing, among them tomato ( $\mathrm{Lyco}$ persicon esculentum Mill.) was selected. This species is not only enlisted by the Guideline but has also been used in laboratory tests where detrimental effects of air pollution were assessed (e.g. Oguntimehin et al. 2010; Ahammed et al. 2012a, b; Daresta et al. 2015).

10 pots were set for each treatment group and for the control. Exposure started when plants reached the 4 true leaf stage (Day 0). The only major deviation from the Guideline was the number of treatments. While in the original protocol only one treatment is prescribed, at the beginning of the exposure, in our test repeated spraying was applied to mimic the continuous exposure posed by air pollution. The sequence of treatments was as follows: Day0, Day7, and Day 14. The test was terminated on Day21, implying 21 days of exposure. Test conditions were in concordance with the Guideline.

Phytotoxic effects were assessed using the following end-points: fresh shoot weight, photosynthetic pigments (chlorophyll $a$ and $b$, carotenoid), protein, and peroxidase (POD). Photosynthetic pigments were measured individually from each plant. For the measurements, a $0.2 \mathrm{~g}$ sample was taken from leaves and homogenized with $15 \mathrm{ml}$ of $80 \%$ acetone. The homogenized sample mixture was centrifuged (4500 rpm, $10 \mathrm{~min}$ ). Absorbance was measured from the supernatant at $440 \mathrm{~nm}, 645 \mathrm{~nm}, 663 \mathrm{~nm}$, and $750 \mathrm{~nm}$.
Homogenised mixture was used for peroxidase activity and total protein content measurements. Peroxidase was measured as described by Nakano and Asada (1981), for total protein content determination the Lowry method was followed with slight modifications (Peterson 1983).

\subsubsection{Sinapis alba Root Growth Inhibition Test}

The test was performed according to ISO 11269-1:2012 Soil quality-Determination of the effects of pollutants on soil flora-Part 1: Method for the measurement of inhibition of root growth. Seeds are exposed to the test substance in the soil or aqueous solution, phytotoxicity is assessed by seedling emergence and early growth.

Filters were placed in petri dishes then $5-5 \mathrm{~cm}^{3}$ sample/control were poured on each filter. 25-25 S. alba seeds were placed in every petri dish at equal distance from each other. Petri dishes were covered and stored in an incubator (darkness, temperature $20-22{ }^{\circ} \mathrm{C}$, exposure $72 \mathrm{~h}$ ). After the pre-set exposure time, root length of each seedling was measured and root length inhibition was calculated. The following equation was used:

$X=\frac{K-M}{K} \times 100$

where $X$ is the root length inhibition (\%) for each concentration, $K$ is the root length of the control plants ( $\mathrm{mm})$, and $M$ is the root length of the plants in each concentration ( $\mathrm{mm}$ ).

The test was run in 4 concentrations, and in two replicates.

\subsection{Statistical Analysis}

Statistical analyses were carried out using one-way ANOVA in R Statistical Environment (R Development Core Team 2017). Tukey HSD post hoc tests were performed in order to reveal pairwise differences (Fig. 2).

\section{Results and Discussion}

\subsection{Analytical Measurements}

Total PAHs concentration was the highest in the autumn extract $(3.08 \mu \mathrm{g} / \mathrm{l})$, followed by winter $(2.54 \mu \mathrm{g} / \mathrm{l})$, spring $(1.16 \mu \mathrm{g} / \mathrm{l})$ and finally, summer $(0.46 \mu \mathrm{g} / \mathrm{l})$.

In autumn and winter, the prevalence of 4 and 5 ring PAHs were detected, the concentration of six ring PAHs was also higher than in the other two seasons (Fig. 3). Interestingly, four ring PAHs were not detected at all in the summer extract.

In the autumn sample, benzo(g.h.i)perylene (BGP), which is considered a marker of gasoline exhaust emissions 


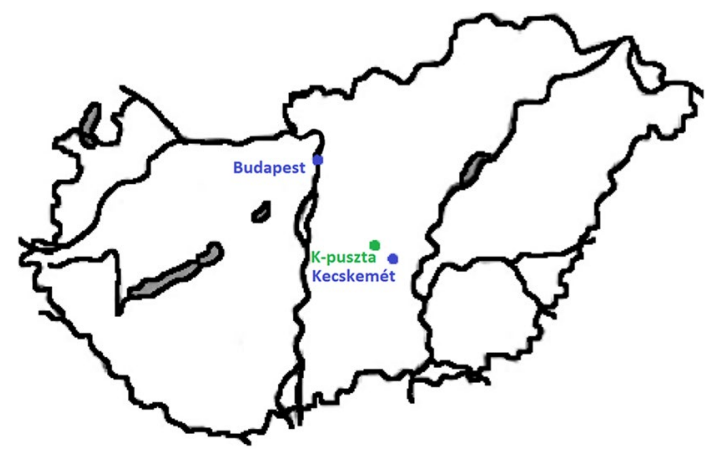

Fig. 1 Location of K-puszta sampling site

(Eiguren-Fernandez et al. 2004) amounted to app. 90\% of 6 ring PAHs.

To compare different seasons, commonly established PAH isomer ratios were used (Yunker et al. 2002). Fluoranthene to fluoranthene plus pyrene (Flt/Flt + Pyr) ratio below 0.5 indicates petroleum while values above 0.5 grass, wood or coal combustion as the potential source. Flt/Flt + Pyr ratios were above 0.5 for winter, spring, and summer samples in the range of $0.52-0.55$ and below 0.5 for the autumn sample (0.48). It indicates somewhat different input for theses seasons: pyrogenic sources in spring, summer, and winter and petrogenic sources in autumn. Benz[a]anthracene plus chrysene $(\mathrm{BaA} / \mathrm{BaA}+\mathrm{CHR})$ ratio over 0.35 implies combustion vegetation and fossil fuel as the potential source, between 0.20 and 0.35 either petroleum or combustion. $\mathrm{BaA} /$ $\mathrm{BaA}+\mathrm{CHR}$ ratios were above 0.35 for the spring, summer, and autumn samples indicating combustion input, and its value was exactly 0.35 indicating mixed sources.

Plotting $\mathrm{BaA} / \mathrm{BaA}+\mathrm{CHR}$ ratio against Flt/Flt + Pyr ratio (Fig. 4) shows that in the case of spring and autumn samples biomass burning can be the most important input while petroleum combustion is an important source in case of the autumn sample. Studies conducted in the European CARBOSOL Project (Present and Retrospective State of Organic versus Inorganic Aerosol over Europe: Implications

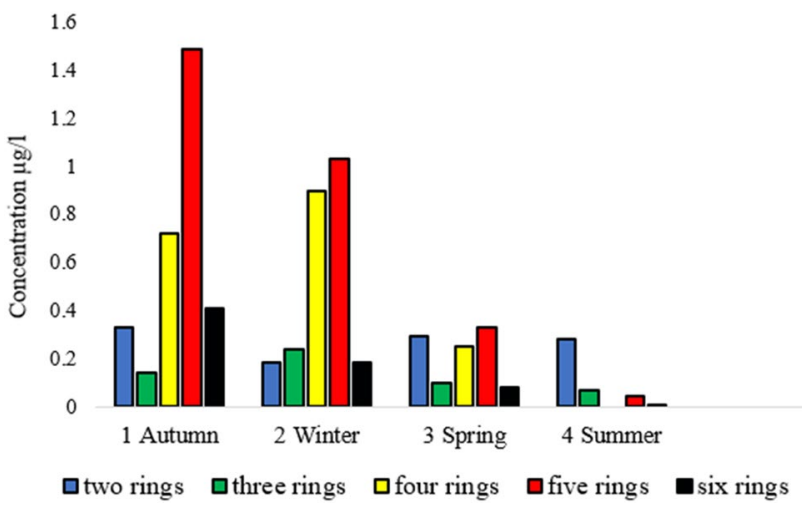

Fig. 3 Distribution of PAHs in the seasonally collected aerosol samples. PAHs are categorised into groups according to the number of rings

for Climate) however revealed that biomass burning is also an important source of emissions (Gelencsér et al. 2007; Pio et al. 2007).

The seasonal pattern found for the K-puszta samples is in concordance with other studies: Hong et al. (2007) for example investigated the seasonal variation of PM10-bound PAHs in Xiamen (China) and experienced the highest concentrations in autumn. Source appointments based on diagnostic ratios and PCA analysis revealed that the main sources of particle-bound PAHs were mainly both gasoline and diesel vehicles exhaust, regardless of the season.

Although K-puszta is a background station without any specific pollution source (Csanádi et al. 2015), in 2014 PM10-bound benzo[a]pyrene concentration levels quite often exceeded the limit value (Szabó Nagy et al. 2017).

\subsection{Ecotoxicological Assessment}

To characterize the ecotoxicity of rural PM samples collected in 4 seasons, three standard protocols were applied: the ISO 21338:2010: water quality — kinetic determination of the inhibitory effects of sediment, other solids and colored
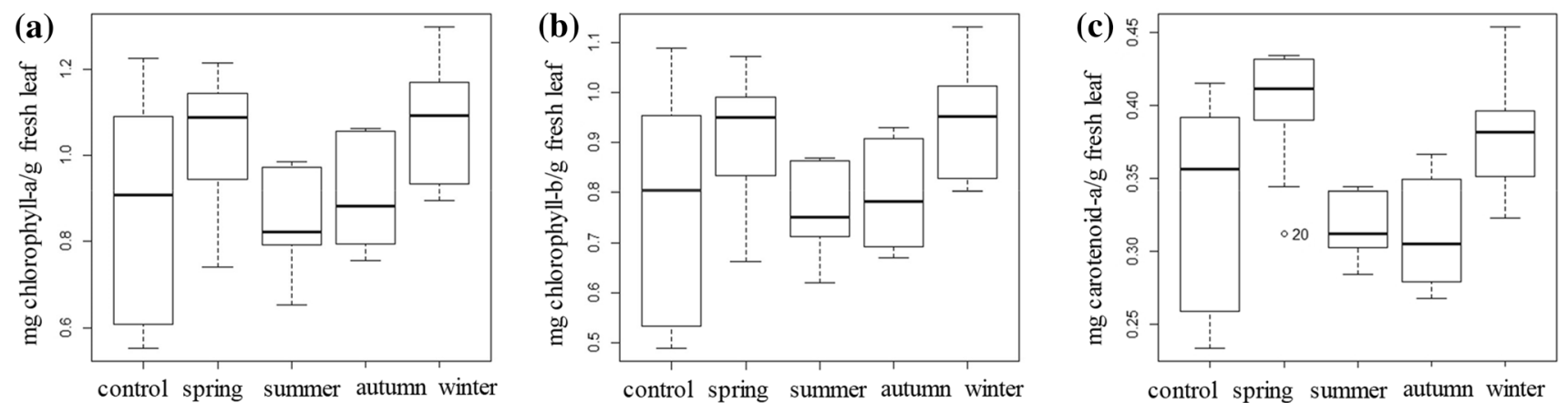

Fig. 2 a Chlorophyll-a, b chlorophyll-b and $\mathbf{c}$ carotenoids concentrations in the treatment groups in comparison to the control 
Fig. 4 Cross plot of $\mathrm{BaA} /$ $\mathrm{BaA}+\mathrm{CHR}$ against Flt/Flt $+\mathrm{Pyr}$

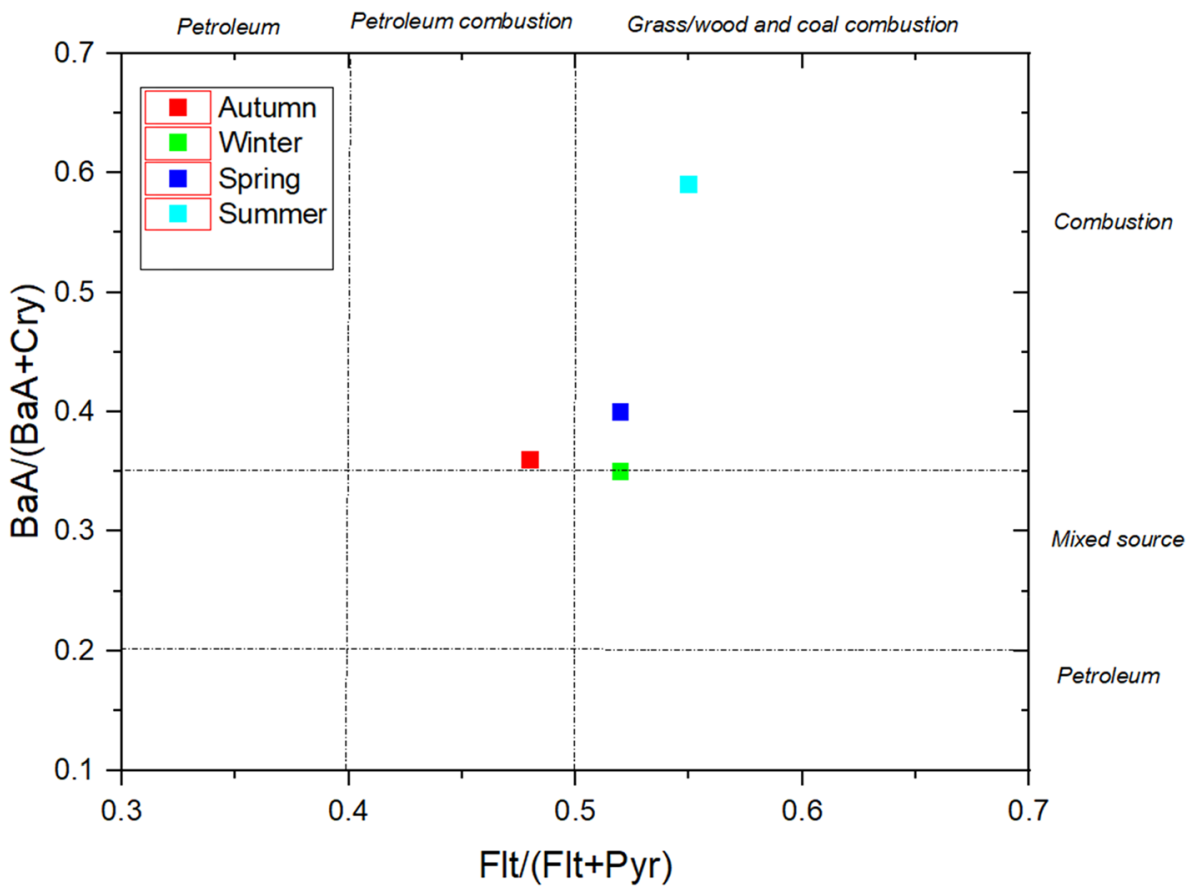

samples on the light emission of Vibrio fischeri (kinetic luminescent bacteria test), the Sinapis alba root growth inhibition test according to ISO 11269-1:2012 Soil qualitydetermination of the effects of pollutants on soil flora-Part 1: Method for the measurement of inhibition of root growth and the No. 227 OECD GUIDELINE FOR THE TESTING OF CHEMICALS: Terrestrial Plant Test: Vegetative Vigour Test (VVT). In this assay, a set of different end-points was used: fresh shoot weight, photosynthetic pigments (chlorophyll $a$ and $b$, carotenoid), protein and peroxidase (POD). Table 1 summarises the ecotoxic/significant response(s) in case of the different bioassays/end-points.

In the Vibrio fischeri bioluminescence inhibition assay, $\mathrm{EC}_{20} \mathrm{~s}$ showed clear dependency from the season: spring: $31.86 \%$; summer: no toxic effect; autumn: $20.02 \%$ and finally, winter: 9.87\%. In our previous work, winter and summer samples collected in K-puszta were compared, covering 2-week sampling in each season. Ecotoxicity of winter samples was found considerably higher, while some summer samples exerted no toxicity (Kováts et al. 2017).

Ecotoxicological studies in general support the higher environmental hazard of PM generated in cold seasons. Aammi et al. (2017) used this bioassay to assess the seasonal pattern in ecotoxicity of PM2.5-10 collected at several locations of Istanbul (Turkey) and found that samples collected during the cold season showed higher toxicity than those obtained in moderate or high temperatures. A similar tendency was found in Nanjing (China) for PM2.5 posed ecotoxicity (Wang et al. 2016) and in Catalonia (Spain) for PM10 samples (Roig et al. 2013).
Table 1 Summary of the results and relative sensitivity of each test/end-points, in comparison to the analytically derived total PAH concentrations

\begin{tabular}{lllll}
\hline & Spring & Summer & Autumn & Winter \\
\hline Vibrio $\mathrm{EC}_{20}$ & $31.86 \%$ & $\mathrm{NT}$ & $20.02 \%$ & $\mathbf{9 . 8 7 \%}$ \\
Root elongation & - & - & - & - \\
VVT, biomass $\left(R^{2}=0.1877\right)$ & - & - & ++ & - \\
VVT, chlorophyll $(a$ and $b$ ) (increase) $(\mathrm{CHLa}$ & - & - & - & + \\
$R^{2}=0.2567$; CHLb $\left.R^{2}=0.2667\right)$ & & & - & - \\
VVT, Carotenoid (increase) $\left(R^{2}=0.3884\right)$ & + & - & - & - \\
VVT, POD $\left(R^{2}=0.034\right)$ & - & - & ++ & ++ \\
VVT, total protein $\left(R^{2}=0.2654\right)$ & - & - & $\mathbf{3 . 0 8}$ & 2.54 \\
Total PAH $\mu \mathrm{g} / \mathrm{l}$ & 1.16 & 0.46 & \\
\hline
\end{tabular}

++ : significant $(p<0.05)$; +: marginally significant $(0.05<p<0.1)$ effect. Highest PAH concentration and highest $V$. fischeri ecotoxicity values are marked by bold. In case of this test, toxicity was expressed as $\mathrm{EC}_{20}$ (the calculated concentration causing $20 \%$ of ecological effect, bioluminescence inhibition in this case)

$N T$ not toxic 
Other bioassays also support this seasonal pattern. Mesquita et al. (2014) for example used Zebrafish embryo cytotoxicity assay to assess PM-bound toxicity in an urban background site in Barcelona (Spain) for 14 months. The highest effects were detected for samples collected during the late autumn months, showing correlation with elevated PAH levels.

The Sinapis alba root growth inhibition assay was unable to detect toxicity. Though it has been used to assess atmospheric particle-bound toxicity (Daresta et al. 2015) and toxicity of polycyclic aromatic hydrocarbons (PAH) contaminated soils (Sverdrup et al. 2003), in our battery it was proven the least sensitive assay.

In case of the Vegetative Vigour Test different end-points were applied which showed not only different sensitivity but also, different stressor-effect relationship patterns.

Biomass measurements were originally included in the OECD Guideline. In our test, treatment with the sample collected in autumn resulted in significantly lower biomass in comparison to the control (ANOVA $f_{4}=2.599, p=0.0486$, Tukey HSD: control-autumn $p=0.0497)$. Reduced growth can be a sensitive end-point due to lower photosynthesis (Wieczorek and Wieczorek 2007), modulated carbon allocation (Desalme et al. 2011b) and can be expressed e.g. in reduced size of above-ground organs such as leaves (Areington et al. 2015). Biomass reduction can be considered an ultimate end-point as protective mechanisms exerted by the plants in stressful environments might be often done at the cost of reduced growth and yield (Ali et al. 2016).

Protein concentration was an additional end-point in our study. It showed significant decrease in comparison to the control in the case of the autumn and winter samples (ANOVA $f_{4}=4.0642, p=0.0068$; Tukey HSD: controlautumn $p=0.032$; control-winter $p=0.007$ ).

Airborne pollutants may induce oxidative stress via overproduction of reactive oxygen species (ROS) which very rapidly react with proteins (Qadir et al. 2016). Proteins might be damaged by the fragmentation of the peptide chain, alteration of the electrical charge of proteins, cross-linking of proteins, and oxidation of specific amino acids (Birben et al. 2012). Verma and Singh (2006) proved that a decrease in the foliar protein content indicates polluted habitats as air pollutants, e.g. exhaust emissions may cause an inhibitory effect on protein synthesis (Kumar and Dubey 1998). Guedes et al. (2009) observed a decrease in the protein content in the urban pollen in comparison to pollen collected at a rural site, most possibly due to the adsorption and accumulation of diesel exhaust particles. The significant reduction in the protein content of autumn and winter samples indicate that PM-bound pollutants elucidated adverse effect.

POD activity in our study proved a less sensitive endpoint, as no significant answer was found based on POD concentrations (ANOVA $f_{4}=1.749, p=0.156$ ). It is somewhat contradictory to published data as POD concentration is expected to increase in stressed environments, in fact, most studies report the elevated concentration of POD in habitats exposed to air pollution (e.g. Manes et al. 1987; Papa et al. 2012; Qadir et al. 2016).

Photosynthetic pigments (chlorophyll $a$, chlorophyll $b$, and carotenoid) showed a somewhat similar pattern, as some of the samples elucidated a slight stimulatory effect. This pattern can be found in cases where the sample contains nutrients that might mask the toxic effect at low concentrations (USEPA 2000). Atmospheric aerosol, in fact, contains a relatively high amount of important plant nutrients such as ammonium, nitrate, potassium, and sulphate (Allen et al. 2010).

Chlorophyll- $a$ and chlorophyll- $b$ content showed marginally significant increase in the winter treatment group in comparison to the control (chlorophyll- $a$ : $f_{4}=3.885$, $p=0.0086$; Tukey HSD: control-winter $p=0.0665$; chlorophyll- $b f_{4}=3.489, p=0.0145$; Tukey HSD: control-winter $p=0.0907)$, Fig. $4 a, b)$. There was a significant increase of carotenoids in the spring sample $\left(f_{4}=7.174, p=0.00015\right.$; Tukey HSD: control-spring $p=0.0254$ ) (Fig. 4c).

The stimulating effect of PM10 urban sample was experienced in our previous work, too (Kováts et al. 2017). A somewhat similar pattern was found in the study of Silva et al. (2015). In this case, aqueous extracts of ash from forest fires was tested on the marine, bioluminescent bacterium Vibrio fischeri. The extracts contained nutrients as $\mathrm{Ca}, \mathrm{S}$, $\mathrm{Mg}, \mathrm{K}$ and Na, but also toxic PAHs. As such, low concentrations resulted in higher luminescence (stimulating effect), but high concentrations elucidated the inhibition of light emittance.

It should be noted, however, that our findings are somewhat contradictory to most results reported in the literature. The majority of the works show that chlorophyll levels decrease in response to foliar application of PAHs (Ren et al. 1996; Oguntimehin and Sakugawa 2008; Desalme et al. 2011a, b). For example, Tomar and Jajoo (2014) observed that FLT treatment elucidated a significant reduction in Chl $a$ and $\mathrm{Chl} b$ and also a reduction in carotenoid level. As a response to air pollution, Fourati et al. (2017) found that the values of chlorophyll and carotenoids in $\mathrm{CP}$ were generally higher in plants from control sites than those from polluted sites, with a more marked difference for carotenoids.

\section{Conclusions}

The study presented here was aimed at characterizing the seasonal pattern of the ecotoxicity of rural PM2.5 samples, using different test organisms (bacteria vs. higher plants) and different test protocols. As such, the sensitivity and reliability of these bioassays were also compared and assessed. 
The seasonal pattern, in general, showed good concordance with studies reported in the literature.

Bioassays showed different sensitivity and stressor-effect pattern. The bioluminescence inhibition bioassay showed medium sensitivity and a clear season-depending pattern. This is a rapid assay (ecotoxicity is assessed after $30 \mathrm{~min}$ of exposure) and is recommended for the first screening of PM ecotoxicity. Considering higher plants applied in our study, the standard root elongation test was not able to detect any toxicity, but the OECD Guideline proved a very sensitive tool. The incorporation of the new end-points made it possible to follow different mechanisms of the ecological effect caused by different components of the samples. Both biomass and protein concentration showed higher toxicity of cold seasons, in concordance with other studies. On the other hand, photosynthetic pigments seemed to indicate the nutrient content of the samples, also indicating that toxic effects could not be manifested.

Results of the higher plant tests might also indicate that warmer seasons pose a much lower environmental hazard. As these seasons are at least partially overlapping with the vegetation period, the actual risk in rural environments seems lower as well. It should also be noted that in these seasons atmospheric particulate matter might have a Janus-faced effect: inhibition on certain organisms due to toxic components and stimulation on others due to nutrient content.

Acknowledgment Open access funding provided by University of Pannonia (PE). The authors acknowledge the financial support of the BIONANO_GINOP-2.3.2-15-2016-00017 project. Aerosol samples were provided by the MTA-PE Air Chemistry Research Group. Special thanks go to the ELGOSCAR-2000 Environmental Technology and Water Management Ltd. (Head Office: 164 Soroksari u. H-1095 Budapest, Laboratory: H-8184 Balatonfuzfo) for analytical measurements.

Funding The work was supported by the BIONANO_GINOP-2.3.215-2016-00017 project.

\section{Compliance with Ethical Standards}

Conflict of interest The authors declare no conflicts of interest.

Open Access This article is licensed under a Creative Commons Attribution 4.0 International License, which permits use, sharing, adaptation, distribution and reproduction in any medium or format, as long as you give appropriate credit to the original author(s) and the source, provide a link to the Creative Commons licence, and indicate if changes were made. The images or other third party material in this article are included in the article's Creative Commons licence, unless indicated otherwise in a credit line to the material. If material is not included in the article's Creative Commons licence and your intended use is not permitted by statutory regulation or exceeds the permitted use, you will need to obtain permission directly from the copyright holder. To view a copy of this licence, visit http://creativecommons.org/licenses/by/4.0/.

\section{References}

Aammi S, Karaca F, Petek M (2017) A toxicological and genotoxicological indexing study of ambient aerosols (PM2.5-10) using in vitro bioassays. Chemosphere 174:490-498. https://doi. org/10.1016/j.chemosphere.2017.01.141

Ahammed GJ, Wang MM, Zhou YH, Xia XJ, Mao WH et al (2012a) The growth, photosynthesis and antioxidant defense responses of five vegetable crops to phenanthrene stress. Ecotox Environ Safe 80:132-139. https://doi.org/10.1016/j.envexpbot.2010.11.009

Ahammed GJ, Yuan HL, Ogweno JO, Zhou YH, Xia XJ (2012b) Brassinosteroid alleviates phenanthrene and pyrene phytotoxicity by increasing detoxification activity and photosynthesis in tomato. Chemosphere 86:546-555. https://doi.org/10.1016/j. chemosphere.2011.10.038

Ali I, Liu B, Farooq M, Ahsan Islam F et al (2016) Toxicological effects of bisphenolA on growth and antioxidant defense system in Oryza sativa as revealed by ultrastructure analysis. Ecotox Environ Safe 124:277-284. https://doi.org/10.1016/j. ecoenv.2015.10.027

Allen AG, Cardoso AA, Wiatr AG, Machado CMD, Paterlini WC, Baker J (2010) Influence of Intensive agriculture on dry deposition of aerosol nutrients. J Braz Chem Soc 21(1):87-97. https:// doi.org/10.1590/S0103-50532010000100014

Areington CA, Varghese B, Ramdhani S (2015) An assessment of morphological, physiological and biochemical biomarkers of industrial air pollution in the leaves of Brachylaena discolor. Water Air Soil Pollut 226:291. https://doi.org/10.1007/s1127 0-015-2541-0

Baran A, Tarnawski M (2013) Phytotoxkit/Phytotestkit and Microtox ${ }^{\circledR}$ as tools for toxicity assessment of sediments. Ecotox Environ Safe 98:19-27. https://doi.org/10.1016/j.ecoenv.2013.10.010

Barbosa R, Dias D, Lapa N, Lopes H, Mendes B (2013) Chemical and ecotoxicological properties of size fractionated biomass ashes. Fuel Process Technol 109:124-132. https://doi.org/10.1016/j. fuproc.2012.09.048

Bierkens J, Klein G, Corbisier P, Van Den Heuvel R, Verschaeve L et al (1998) Comparative sensitivity of 20 bioassays for soil quality. Chemosphere 37:2935-2947. https://doi.org/10.1016/S0045 $-6535(98) 00334-8$

Birben E, Sahiner UM, Sackesen C, Erzurum S, Kalayci O (2012) Oxidative stress and antioxidant defense. World Allergy Organ J 5(1):9-19. https://doi.org/10.1097/WOX.0b013e3182439613

Csanádi Z, Szabó Nagy A, Szabó J, Erdős J (2015) Temporal variation of PM10-bound benzo(a)pyrene concentration in an urban and a rural site of Northwestern Hungary. Int J Environ Chem Ecol Geol Geophys Eng 9(8):828-832

Daresta BE, Italiano F, de Gennaro G, Trotta M, Tutino M, Veronico P (2015) Atmospheric particulate matter (PM) effect on the growth of Solanum lycopersicum cv. Roma plants. Chemosphere 119:3742. https://doi.org/10.1016/j.chemosphere.2014.05.054

Desalme D, Binet P, Bernard N, Gilbert D, Toussaint ML, Chiapusio G (2011a) Atmospheric phenanthrene transfer and effects on two grassland species and their root symbionts: a microcosm study. Environ Exp Bot 71:146-151. https://doi.org/10.1016/j.envex pbot.2010.11.009

Desalme D, Binet P, Epron D, Bernard N, Gilbert D et al (2011b) Atmospheric phenanthrene pollution modulates carbon allocation in red clover (Trifolium pratense L.). Environ Pollut 159:2759_ 2765. https://doi.org/10.1016/j.envpol.2011.05.015

Eiguren-Fernandez A, Miguel AH, Froines JR, Thurairatnam S, Avol EA (2004) Seasonal and spatial variation of polycyclic aromatic hydrocarbons in vapor-phase and PM2.5 in Southern California Urban and Rural Communities. Aerosol Sci Technol 38(5):447455. https://doi.org/10.1080/02786820490449511 
El-Alawi YS, McConkey BJ, George Dixon D, Greenberg BM (2002) Measurement of short- and long-term toxicity of polycyclic aromatic hydrocarbons using luminescent bacteria. Ecotox Environ Safe 51(1):12-21. https://doi.org/10.1006/eesa.2001.2108

European Environmenal Agency (2017) Air quality in Europe-2017 report. EEA Report No 13/2017, Luxembourg

Evagelopoulos V, Zoras S, Samaras P, Triantafyllou AG, Albanis TA, Kassomenos P (2009) Toxicity of fine and coarse atmospheric particles using Vibrio fischeri. In: 2" international conference on environmental management, engineering, planning and economics (CEMEPE 2009) \& SECOTOX conference

Filep Á, Drinovec L, Palágyi A, Manczinger L, Cs Vágvölgyi et al (2015) Source specific cyto- and genotoxicity of atmospheric aerosol samples. Aerosol Air Qual Res 15:2325-2331

Fourati R, Scopa A, Ahmed CB, Abdallah FB, Terzano R et al (2017) Leaf biochemical responses and fruit oil quality parameters in olive plants subjected to airborne metal pollution. Chemosphere 168:514-522. https://doi.org/10.1016/j.chemosphere.2016.11.041

Gelencsér A, May B, Simpson D, Sánchez-Ochoa A, Kasper-Giebl A et al (2007) Source apportionment of PM2.5 organic aerosol over Europe: primary/secondary, natural/anthropogenic, and fossil/biogenic origin. J Geophys Res 112:D23S04. https://doi. org/10.1029/2006jd008094

Guedes A, Ribeiroc N, Ribeiroc H, Oliveirac M, Noronhaa F, Abreuc I (2009) Comparison between urban and rural pollen of Chenopodium alba and characterization of adhered pollutant aerosol particles. Aerosol Sci 40:81-86. https://doi.org/10.1016/j.jaero sci.2008.07.012

Hong HS, Yin HL, Wang XH, Ye CX (2007) Seasonal variation of PM10-bound PAHs in the atmosphere of Xiamen, China. Atmos Res 85:429-441. https://doi.org/10.1016/j.atmosres.2007.03.004

Horváth L, Sutton MA (1998) Long-term record of ammonia and ammonium concentrations at K-puszta, Hungary. Atmos Environ 32(3):339-344. https://doi.org/10.1016/S1352-2310(97)00046-0

Health Effects Institute, Perspectives (2002) Understanding the health effects of components of the particulate matter mix: progress and next steps. HEI Publication, Boston

Kessler N, Schauer JJ, Yagur-Kroll S, Melamed S, Tirosh O et al (2012) A bacterial bioreporter panel to assay the cytotoxicity of atmospheric particulate matter. Atmos Environ 63:94-101. https://doi. org/10.1016/j.atmosenv.2012.09.048

Kováts N (2020) Assessment of the ecotoxicity of airborne particulate matter. In: D'Mello JPF (ed) A handbook of environmental toxicology: human disorders and ecotoxicology. CABI Publishers, Wallingford, pp 424-436

Kováts N, Horváth E, Eck-Varanka B, Csajbók E, Hoffer A (2017) Adapting the vegetative vigour terrestrial plant test for assessing ecotoxicity of aerosol samples. Environ Sci Pollut Res 24:1529115298. https://doi.org/10.1007/s11356-017-9103-5

Kumar GS, Dubey PS (1998) Differential response and detoxifying mechanism of Cassia siamea Lam. and Dalbergia sissoo Roxb. of different ages to SO2 treatment. J Environ Biol 9(3):243-249

Lappalainen J, Juvonen R, Vaajasaari K, Karp M (1999) A new flash method for measuring the toxicity of solid and colored samples. Chemosphere 38:1069-1083. https://doi.org/10.1016/S0045 $-6535(98) 00352-X$

Lappalainen J, Juvonen R, Nurmi J, Karp M (2001) Automated color correction method for Vibrio fischeri toxicity test. Comparison of standard and kinetic assays. Chemosphere 45:635-641. https ://doi.org/10.1016/S0045-6535(00)00579-8

Maenhaut W, Chi X, Wang W, Cafmeyer J, Yasmeen F, Vermeylen R, Szmigielsk K, Janssens IA, Claeys M (2017) Contribution from selected organic species to $\mathrm{PM}_{2.5}$ aerosol during a summer field campaign at K-Puszta, Hungary. Atmosphere 8:221. https://doi. org/10.3390/atmos8110221
Manes F, Federico R, Bruno F (1987) Peroxidase activity in Nicotina tabacum L. treated with simulated acid rain. Phytopath Medit 25:76-79

Marti E, Sierra J, Sanchez-Soberon F, Rovira J, Roig N et al (2015) In vitro tests to assess toxic effects of airborne PM10, PM2.5 and PM1 samples near cement plants. Toxicol Lett 238S:S56-S383. https://doi.org/10.1016/j.toxlet.2015.08.364

Mesquita SR, van Drooge BL, Reche C, Guimarães L, Grimalt JO et al (2014) Toxic assessment of urban atmospheric particle-bound PAHs: relevance of composition and particle size in Barcelona (Spain). Environ Pollut 184:555-562. https://doi.org/10.1016/j. envpol.2013.09.034

Morville S, Delhomme O, Millet M (2011) Seasonal and diurnal variations of atmospheric PAH concentrations between rural, suburban and urban areas. Atmos Pollut Res 2:366-373. https://doi. org/10.5094/APR.2011.041

Nakano Y, Asada K (1981) Hydrogen peroxide is scavenged by ascorbate specific peroxidase in spinach chloroplasts. Plant Cell Physiol 22:867-880. https://doi.org/10.1093/oxfordjournals.pcp.a076232

Oguntimehin I, Sakugawa H (2008) Fluoranthene fumigation and exogenous scavenging of reactive oxygen intermediates (ROI) in evergreen Japanese red pine seedlings (Pinus densiflora Sieb. et. Zucc.). Chemosphere 72:747-754. https://doi.org/10.1016/j. chemosphere.2008.03.022

Oguntimehin I, Eissa F, Sakugawa H (2010) Negative effects of fluoranthene on the ecophysiology of tomato plants (Lycopersicon esculentum Mill) Fluoranthene mists negatively affected tomato plants. Chemosphere 78:877-884. https://doi.org/10.1016/j.chemo sphere.2009.11.030

Papa S, Bartoli G, Nacca F, D’Abrosca B, Cembrola E et al (2012) Trace metals, peroxidase activity, PAHs contents and ecophysiological changes in Quercus ilex leaves in the urban area of Caserta (Italy). J Environ Manag 113:501-509. https://doi.org/10.1016/j. jenvman.2012.05.032

Pašková V, Hilscherová K, Feldmannová M, Bláha L (2006) Toxic effects and oxidative stress in higher plants exposed to polycyclic aromatic hydrocarbons and their $N$-heterocyclic derivatives. Environ Toxicol Chem 25(12):3238-3245. https://doi. org/10.1897/06-162R.1

Peterson GL (1983) Determination of total protein. Methods Enzymol 91:86-105. https://doi.org/10.1016/S0076-6879(83)91014-5

Pio CA, Legrand M, Oliveira T, Afonso J, Santos C et al (2007) Climatology of aerosol composition (organic versus inorganic) at nonurban sites on a west-east transect across Europe. J Geophys Res 112:D23S02. https://doi.org/10.1029/2006jd008038

Qadir SU, Raja V, Siddiqui WA (2016) Morphological and biochemical changes in Azadirachta indica from coal combustion fly ash dumping site from a thermal power plant in Delhi, India. Ecotox Environ Safe 129:320-328. https://doi.org/10.1016/j.ecoen v.2016.03.026

R Development Core Team (2017) R: a language and environment for statistical computing. R Foundation for Statistical Computing, Vienna, Austria. http://www.R-project.org/

Reche C, Querol X, Alastuey A, Viana M, Pey J et al (2011) New considerations for PM, Black Carbon and particle number concentration for air quality monitoring across different European cities. Atmos Chem Phys 11:6207-6227. https://doi.org/10.5194/ acp-11-6207-2011

Ren L, Zeiler LF, Dixon DG, Greenberg BM (1996) Photoinduced effects of polycyclic aromatic hydrocarbons on Brassica napus (Canola) during germination and early seedling development. Ecotox Environ Safe 33:73-80. https://doi.org/10.1006/ eesa. 1996.0008

Roig N, Sierra J, Rovira J, Schuhmacher M, Domingo JL, Nadal M (2013) In vitro tests to assess toxic effects of airborne PM10 samples. Correlation with metals and chlorinated dioxins and furans. 
Sci Total Environ 443:791-797. https://doi.org/10.1016/j.scito tenv.2012.11.022

Shen G, Wang W, Yang Y, Ding J, Xue M et al (2011) Emissions of PAHs from indoor crop residue burning in a typical rural stove: emission factors, size distributions, and gas- particle partitioning. Environ Sci Technol 45:1206-1212. https://doi.org/10.1021/ es102151w

Silva V, Pereira JL, Campos I, Keizer JJ, Gonçalves F, Abrantes N (2015) Toxicity assessment of aqueous extracts of ash from forest fires. CATENA 135:401-408. https://doi.org/10.1016/j.caten a.2014.06.021

Sverdrup LE, Krogh PH, Nielsen T, Kjær C, Stenersen J (2003) Toxicity of eight polycyclic aromatic compounds to red clover (Trifolium pratense), ryegrass (Lolium perenne), and mustard (Sinapsis alba). Chemosphere 53:993-1003. https://doi.org/10.1016/S0045 $-6535(03) 00584-8$

Szabó Nagy A, Szabó J, Zs Csanádi, Erdős J (2017) Carcinogenic polycyclic aromatic hydrocarbons in urban air particulate matter. Int J Environ Ecol Eng 11(6):490-494

Teixeira EC, Agudelo-Castañeda DM, Fachel JMG, Leal KA, de Oliveira Garcia K, Wiegand F (2012) Source identification and seasonal variation of polycyclic aromatic hydrocarbons associated with atmospheric fine and coarse particles in the Metropolitan Area of Porto Alegre, RS, Brazil. Atmos Res 118:390-403. https ://doi.org/10.1016/j.atmosres.2012.07.004

Tomar RS, Jajoo A (2014) Fluoranthene, a polycyclic aromatic hydrocarbon, inhibits light as well as dark reactions of photosynthesis in wheat (Triticum aestivum). Ecotox Environ Safe 109:110-115. https://doi.org/10.1016/j.ecoenv.2014.08.009

USEPA (2000) Method guidance and recommendations for whole effluent toxicity (WET) Testing (40 CFR Part 136). EPA 821-B00-004. U.S. Environmental Protection Agency, Office of Water

Valavanidis A, Fiotakis K, Vlahogianni T, Bakeas EB, Triantafillaki $S$ et al (2006) Characterization of atmospheric particulates, particle-bound transition metals and polycyclic aromatic hydrocarbons of urban air in the centre of Athens (Greece). Chemosphere 65:760-768. https://doi.org/10.1016/j.chemosphere.2006.03.052

Verma A, Singh SN (2006) Biochemical and ultrastructural changes in plant foliage exposed to auto-pollution. Environ Monit Assess 120:585-602. https://doi.org/10.1007/s10661-005-9105-5

Verma V, Rico-Martinez R, Kotra N, Rennolds C, Liu J et al (2013) Estimating the toxicity of ambient fine aerosols using freshwater rotifer Brachionus calyciflorus (Rotifera: Monogononta). Environ Pollut 182:379-384. https://doi.org/10.1016/j.envpol.2013.07.037

Wang WH, Wong MH, Leharne S, Fisher B (1998) Fractionation and biotoxicity of heavy metals in urban dusts collected from Hong Kong and London. Environ Geochem Health 20:185-198. https ://doi.org/10.1023/A:1006530300522

Wang W, Shi C, Yan Y, Yang Y, Zhou B (2016) Eco-toxicological bioassay of atmospheric fine particulate matter (PM2.5) with Photobacterium phosphoreum T3. Ecotox Environ Safe 133:226-234. https://doi.org/10.1016/j.ecoenv.2016.07.024

WHO (2013) Health effects of particulate matter. World Health Organization Regional Office for Europe, Copenhagen, $\mathrm{p} 20$

Wieczorek JK, Wieczorek ZJ (2007) Phytotoxicity and accumulation of anthracene applied to the foliage and sandy substrate in lettuce and radish plants. Ecotox Environ Safe 66:369-377. https://doi. org/10.1016/j.ecoenv.2005.10.002

Yunker MB, Macdonald RW, Vingarzan R, Mitchell RH, Goyette D, Sylvestre S (2002) PAHs in the Fraser River basin: a critical appraisal of PAH ratios as indicators of PAH source and composition. Org Geochem 33:489-515

Zhao Y, Lin Z, Jia R, Li G, Xi Z, Wang D (2014) Transgenerational effects of traffic-related fine particulate matter (PM2.5) on nematode Caenorhabditis elegans. J Hazard Mater 274:106-114. https ://doi.org/10.1016/j.jhazmat.2014.03.064 